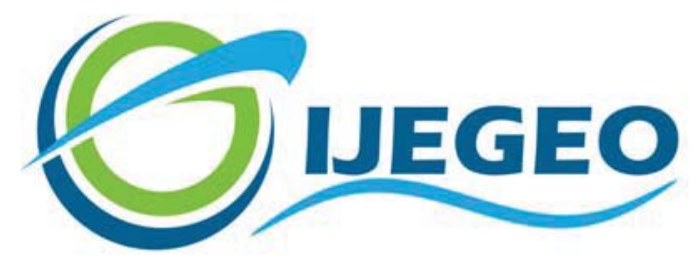

International Journal of Environment and Geoinformatics (IJEGEO) is an international, multidisciplinary, peer reviewed, open access journal.

\title{
Egg White Cryogel for Removal of Methylene Blue from Aqueous Solution
}

\section{Umit GULYUZ}

\author{
Chief in Editor \\ Prof. Dr. Cem Gazioğlu \\ Co-Editors
}

Prof. Dr. Dursun Zafer Şeker, Prof. Dr. Şinasi Kaya,

Prof. Dr. Ayşegül Tanık and Assist. Prof. Dr. Volkan Demir

Editorial Committee (September 2021)

Assoc. Prof. Dr. Abdullah Aksu (TR), Assit. Prof. Dr. Uğur Algancı (TR), Prof. Dr. Bedri Alpar (TR), Assoc. Prof. Dr. Aslı Aslan (US), Prof. Dr. Levent Bat (TR), Prof. Dr. Paul Bates (UK), İrşad Bayırhan (TR), Prof. Dr. Bülent Bayram (TR), Prof. Dr. Luis M. Botana (ES), Prof. Dr. Nuray Çağlar (TR), Prof. Dr. Sukanta Dash (IN), Dr. Soofia T. Elias (UK), Prof. Dr. A. Evren Erginal (TR), Assoc. Prof. Dr. Cüneyt Erenoğlu (TR), Dr. Dieter Fritsch (DE), Prof. Dr. Çiğdem Göksel (TR), Prof.Dr. Lena Halounova (CZ), Prof. Dr. Manik Kalubarme (IN), Dr. Hakan Kaya (TR), Assist. Prof. Dr. Serkan Kükrer (TR), Assoc. Prof. Dr. Maged Marghany (MY), Prof. Dr. Michael Meadows (ZA), Prof. Dr. Nebiye Musaoğlu (TR), Prof. Dr. Masafumi Nakagawa (JP), Prof. Dr. Hasan Özdemir (TR), Prof. Dr. Chryssy Potsiou (GR), Prof. Dr. Erol Sarı (TR), Prof. Dr. Maria Paradiso (IT), Prof. Dr. Petros Patias (GR), Prof. Dr. Elif Sertel (TR), Prof. Dr. Nüket Sivri (TR), Prof. Dr. Füsun Balık Şanlı (TR), Prof. Dr. Uğur Şanlı (TR), Duygu Ülker (TR), Prof. Dr. Seyfettin Taş (TR), Assoc. Prof. Dr. Ömer Suat Taşkın (TR), Assist. Prof. Dr. Tuba Ünsal (TR), Dr. Manousos Valyrakis (UK), Dr. İnese Varna (LV), Dr. Petra Visser (NL), Prof. Dr. Selma Ünlü (TR), Assoc. Prof. Dr. Oral Yağcı (TR), Prof. Dr. Murat Yakar (TR), Assoc. Prof. Dr. İ. Noyan Yılmaz (AU); Assit. Prof. Dr. Sibel Zeki (TR) 
Research Article

\title{
Egg White Cryogel for Removal of Methylene Blue from Aqueous Solution
}

\author{
Ümit Gülyüz (iD) \\ Department of Chemistry and Chemical Processing Technologies, Kirklareli University, 39750 Luleburgaz, Kirklareli, Turkey.
}

E-mail: umitgulyuz@klu.edu.tr

Received 14 Feb. 2020

Accepted 22 Feb. 2021

How to cite: Gulyuz, U. (2021). Egg White Cryogel for Removal of Methylene Blue from Aqueous Solution. International Journal of Environment and Geoinformatics (IJEGEO), 8(3): 328-336. doi. 10.30897/ijegeo.879835

\begin{abstract}
Macroporous egg white (EW) cryogel synthesized by cryogelation at sub-zero temperature $\left(-18^{\circ} \mathrm{C}\right)$ with crosslinker glutaraldehyde (GA) was tested in the adsorption of methylene blue (MB) as a model pollutant from aqueous solution. The characterization of obtained cryogel was carried out using Fourier-transform infrared spectroscopy and scanning electron microscopy. The effects of initial dye concentration, $\mathrm{pH}$ and contact time parameters on the adsorption were systematically evaluated. The pseudo-first order and pseudo-second order models were used to predict the adsorption kinetics. The adsorption followed the pseudo-second order model. Two isotherm models called Langmuir and Freundlich were applied on the experimental data to predict the maximum adsorption capacity and explain the process of adsorption. Langmuir isotherm model provided the best fit with maximum adsorption capacity of $56.18 \mathrm{mg} \mathrm{MB} / \mathrm{g}$ cryogel. The dye adsorbed EW cryogel was easily regenerated and used several times with no noticeable reduction of capacity. The electrostatic attraction was the main adsorption mechanism of MB on the cryogel, especially at slightly basic $\mathrm{pH}$. Its easy preparation, low-cost and good adsorption property make the EW cryogel a promising adsorbent for environmental applications.
\end{abstract}

Keywords: Cryogel, Biosorbent, Egg White, Methylene Blue, Adsorption

\section{Introduction}

Environmental pollution has increased seriously in direct proportion to the increase in industrial and human activities all over the world. Especially water is contaminated with toxic substances such as dyes and heavy metals, etc. Water pollution with dyes used in various areas such as textiles, printing, plastics and cosmetics is increasing more than ever, so that water treatment has become a very important issue for environmental protection today. These dyes can be dangerous to aquatic living organisms. Methylene blue (MB) is a cationic dye which can be more toxic than anionic dyes due its interaction with anionic surface of cell membrane and penetration into the living cells (Bayramoglu et al., 2009; He et al., 2013). Moreover, $\mathrm{MB}$ as well as many dyes can cause many serious health problems in humans like increased heartbeat, vomiting, shock, cyanosis, jaundice, tissue necrosis and even cancer.

Biological treatment, coagulation/flocculation, photocatalysis, membrane filtration, adsorption and chemical oxidation are the most commonly applied techniques for removing pollutants from wastewaters (Bolto and Gregory, 2007; Hasanpour and Hatami, 2020; Kanaujiya et al., 2019; Karabayir et al., 2019; Kumar and Sivanesan, 2006). Among them, adsorption seems more effective and feasible thanks to its advantages such as ease of application, low-cost and availability of various adsorbents. During the last few decades, researchers have been introduced different types of adsorbents including natural materials, biosorbents and functional polymeric materials with high adsorption capacities, reusable and easy preparation (Crini, 2006; Dalaran et al., 2011; Erdem et al., 2017). Bio-based polymeric materials have attracted great attention due to their ability to be nontoxic and biodegradable. For example, alginate, chitin, chitosan, starch, carboxymethylcellulose based hydrogels have been tested as adsorbents (Crini and Badot, 2008; Dragan and Loghin, 2013; Huang et al., 2011; Rocher et al., 2010). Egg white (EW), mainly consists of $\sim 90 \%$ water and $\sim 10 \%$ protein, is a good alternative biopolymer to fabricate adsorbent owing to cheap and biodegradable without leading to secondary pollution. For example, egg white/polyethyleneimine hydrogel crosslinked with epichlorohydrin was prepared for removing heavy metal ions (Godiya et al., 2020). In another study, EW biosorbent was prepared by crosslinking with $N, N_{0}$-methylenebis(acrylamide) for removing anionic indigo carmine (Oymak and Bağda, 2018). Unlike these two studies, it was aimed here to prepare macroporous EW cryogel as a biosorbent.

Cryogelation or cryotropic gelation is one of the several methods to fabricate porous materials (Dinu et al., 2007; Lozinsky et al., 2001). The hydrogel obtained by this method is called cryogel. During cryogelation, solvent is frozen at temperatures below freezing point of the reaction solution and crystals are formed as a porogen. It is generally performed at subzero temperature because most of the time water is 
used as a solvent. After thawing, the structure with interconnected large pores in the cryogels is obtained, which provide not only sufficient surface area for adsorption but also fast mass transfer of substances. Interconnected macropores even could facilitate the flow of liquids such as wastewater at low back pressure.

In the present study, inexpensive and abundant EW as a biopolymer was crosslinked with glutaraldehyde (GA) at $-18^{\circ} \mathrm{C}$ to prepare a cryogel for the removal of MB. The synthesis procedure was simple and consists of only mixing with GA and subsequently cooling. The functional groups and morphology of prepared cryogel were analyzed. The effects of $\mathrm{pH}$ (3-9), initial dye concentration (10-180 $\mathrm{mg} / \mathrm{L})$ and time $(0.5-48 \mathrm{~h})$ on the adsorption were systematically investigated. The adsorption mechanism of MB on the EW cryogel was predicted by applying various isotherm and kinetic models on the experimental data.

\section{Materials and Methods}

Chicken eggs (Local market), methylene Blue (MB, Merck), glutaraldehyde solution 25\% (GA, Merck), hydrochloric acid ( $\mathrm{HCl}$, Merck), sodium hydroxide ( $\mathrm{NaOH}$, Merck) and $n$-hexane (Lab-scan) were used without further purification.

EW cryogel was fabricated using glutaraldehyde as a crosslinker (Balaji et al., 2019). Firstly, the EW was carefully separated from the yolk in Figure 1. Collected EW was stirred for $10 \mathrm{~min}$ to make homogeneous. Then, $10 \mathrm{~mL}$ of $\mathrm{EW}$ was mixed with $200 \mu \mathrm{L}$ glutaraldehyde solution (final concentration $0.5 \%$ ) and $40 \mu \mathrm{L}$ concentrated $\mathrm{HCl}$. The reaction solution was immediately poured into $1 \mathrm{~mL}$ plastic syringes and placed at $-18^{\circ} \mathrm{C}$ for $24 \mathrm{~h}$. After cryogelation, the cryogel samples were immersed in large amount of distilled water at room temperature to extract dissolved and unreacted reagents by changing water over several days. The samples were then dried.

The dried EW cryogels were swollen in water up to the equilibrium to determine the swelling ratio $(S R)$ which is calculated by equation given below,

$S R=\frac{m_{S}}{m_{d}}$

where $m_{d}$ and $m_{s}$ are the weights of dried and corresponding swollen gel sample at equilibrium, respectively. The pore volume $\left(V_{p}\right)$ was determined by immersing the dried sample in $n$-hexane as a poor solvent for $1 \mathrm{~h}$ and measuring the weight of the sample at swollen state (Dinu et al., 2011). $V_{p}$ was calculated by equation given below,

$V_{p}=\frac{m_{s}-m_{d}}{m_{d} d_{h}}$

where $d_{h}$ is the density of $n$-hexane. The porosity ( $\left.P \%\right)$ was estimated by squeezing the cryogel swollen in water and removing free water from macropores (Henderson et al., 2013). P\% was calculated by equation given below,

$P \%=\frac{m_{s}-m_{s q}}{m_{s}} x 100$

where $m_{s q}$ is the weight of squeezed cryogel sample.

The functional groups in the cryogel were analyzed using a Fourier transform infrared spectroscopy (FTIR, Perkin-Elmer) in the range $4000-450 \mathrm{~cm}^{-1}$. The microstructure of the cryogel was visualized using a scanning electron microscope (SEM, FEI/Quanta FEG 250) at various magnifications between 30 and 1000 times. The sample was sprayed with platinum and observed under an operating voltage of $20 \mathrm{kV}$. The pore sizes were measured from SEM images using Image $\mathbf{J}$ software.

The dye adsorption in aqueous solution was systematically evaluated by a batch procedure. UV spectrophotometry (Shimadzu UV 2600) was used to monitor the spectra and measure the absorbance of dye in solution. Before adsorption experiment, the calibration curve of MB at $664 \mathrm{~nm}$ was obtained by preparing solutions with different concentrations. $\sim 10$ mg cryogel samples were added into $10 \mathrm{~mL}$ solution of a certain concentration of $\mathrm{MB}$ at different initial $\mathrm{pH}$ values. The $\mathrm{pH}$ was adjusted using $1 \mathrm{M} \mathrm{NaOH}$ and $1 \mathrm{M}$ $\mathrm{HCl}$ solutions. The experiments were performed in an isothermal shaker at $25^{\circ} \mathrm{C}$ and $120 \mathrm{rpm}$. The absorbance of residual dye in solution was measured and then the concentration was determined from calibration curve. The equilibrium adsorption capacity $q_{e} \quad(\mathrm{mg} / \mathrm{g})$ (dye/dried cryogel) was calculated by equation given below,

$q_{e}=\frac{\left(C_{o}-C_{e}\right) V}{m}$

where $C_{o}$ and $C_{e}(\mathrm{mg} / \mathrm{L})$ are the initial and residual concentrations of dye in aqueous solutions, respectively. $V(\mathrm{~mL})$ is the volume of dye solution and $m(\mathrm{mg})$ is the weight of dried EW cryogel.

The regeneration and reusability of the cryogel were performed in repetitive adsorption/desorption cycles. The dye adsorbed cryogel after the adsorption step (15 $\mathrm{mg} / \mathrm{L}$ of initial dye concentration) was immersed into $1 \mathrm{M}$ HCI solution $(20 \mathrm{~mL})$ and shaken for $2 \mathrm{~h}$. After this process was repeated twice, the cryogel was removed from the solution and rinsed with water for neutralization. In this way, the cryogel was regenerated for re-adsorption. The reusability was investigated by applying four adsorption/desorption cycles. From the absorbed dye concentration, the regeneration capacity $\left(R_{c} \%\right)$ for each cycle was calculated by equation given below (Godiya et al., 2020),

$R_{c} \%=\frac{C_{o}-C_{r}}{C_{o}-C_{i}} \times 100$ 
where $C_{i}$ and $C_{r}$ are the residual concentrations of dye in aqueous solution $(\mathrm{mg} / \mathrm{L})$ after initial cycle and regeneration, respectively.

For kinetic study, the adsorption experiments as a function of contact time $(15 \mathrm{mg} / \mathrm{L}$ of aqueous dye solution at $\mathrm{pH} 9)$ were carried out. The adsorption capacity in any time $q_{t}(\mathrm{mg} / \mathrm{g})$ was calculated by equation given below,

$q_{t}=\frac{\left(C_{o}-C_{t}\right) V}{m}$

where $C_{t}$ is the dye concentration in aqueous solution $(\mathrm{mg} / \mathrm{L})$ at any time $t$.

\section{Results and Discussion}

In our approach, the EW cryogel was obtained by crosslinking with GA via cryogelation method. The characterization of network structure was performed by FTIR. The spectra of the EW crosslinked with and without GA are given in Figure 2. The peaks at 1538 and $1627 \mathrm{~cm}^{-1}$ correspond to Amide II $(\mathrm{N}-\mathrm{H}$ bending vibration) and Amide $\mathrm{I}(\mathrm{C}=\mathrm{O}$ stretching vibration), respectively. These two characteristic peaks related to the functional groups are commonly observed in proteins (Garidel \& Schott, 2006). The strong peak appeared at $3281 \mathrm{~cm}^{-1}$ corresponds to the Amide A band $(\mathrm{N}-\mathrm{H}$ stretching vibration). Also, the peaks at 1397 and $2874 \mathrm{~cm}^{-1}$ belong to the amide bands. According to these spectra, it is seen that the EW retained its functional groups after crosslinking (Balaji et al., 2019).

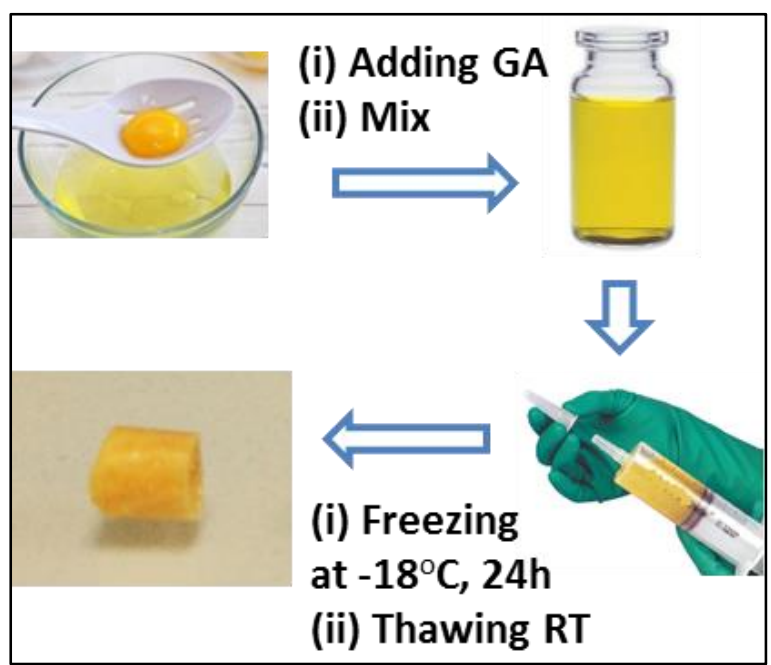

Figure 1. The synthetic preparation procedure of the EW cryogel.

As emphasized earlier, macro size and interconnectivity of pores are characteristic features of cryogels. The properties of swelling ratio $(S R)$, pore volume $\left(V_{p}\right)$ and porosity $(P \%)$ are given in Table 1 . It swelled about 10-fold with respect to its dry state. $V_{p}$ was found by immersing the dried samples in $n$-hexane as a poor solvent which causes no swelling but instead fills its pores. The uptake of solvent reflected the pore volume of the sample with $2.7 \pm 0.2 \mathrm{~mL} / \mathrm{g}$ since the cryogel did not swell. Also, the estimated average porosity was found to be $71 \%$ by squeezing it mechanically. The squeezability of cryogel without destroying its network reflects the high pore interconnectivity. These results were supported by visualizing the microstructure of the cryogel directly using SEM (Figure 3). The morphology from SEM images also revealed that the cryogel possesses large and interconnected pores. The pore sizes of the cryogel were measured in the range from 50 to $150 \mu \mathrm{m}$. These interconnected pores facilitate dye diffusion reaching the active sites of the cryogel.

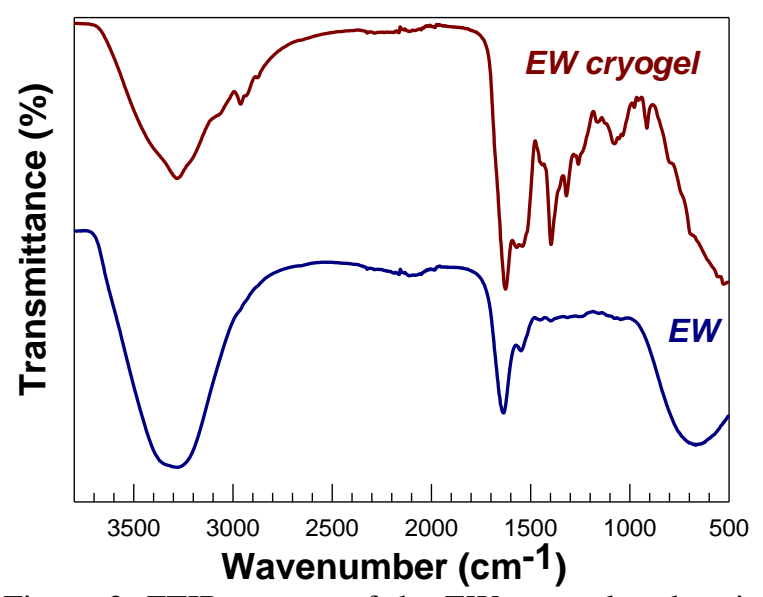

Figure 2. FTIR spectra of the EW cryogel and native EW without crosslinking.

Table 1. The parameters of the EW cryogel.

\begin{tabular}{ccc}
\hline$S R(\mathrm{~g} / \mathrm{g})$ & $V_{p}(\mathrm{~mL} / \mathrm{g})$ & $P \%$ \\
\hline $9.7 \pm 0.7$ & $2.7 \pm 0.2$ & $71 \pm 2$ \\
\hline
\end{tabular}
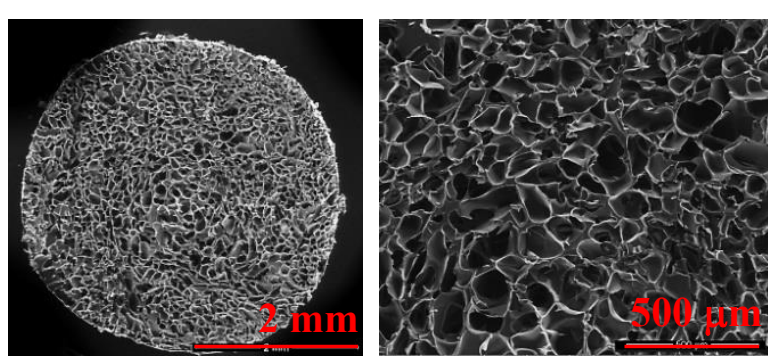

Figure 3. SEM images of dry EW cryogel. Scaling bars $=2 \mathrm{~mm}$ (left) and $500 \mu \mathrm{m}$ (right).

\section{Adsorption of dye}

The effects of solution $\mathrm{pH}$, initial dye concentration and contact time were studied in detail. The $\mathrm{pH}$ is one of the main factors affecting mechanism of adsorption or desorption of dyes (Hu et al., 2018). The experiments were initially performed at various $\mathrm{pH}$ values in the range of 3 and 9 to determine the optimum solution medium. In Figure 4, the adsorption capacity of $\mathrm{MB}$ on $\mathrm{EW}$ cryogel was $\mathrm{pH}$ dependent and reached high values above $\mathrm{pH} 6$. The amount of $\mathrm{MB}$ adsorption significantly increased from $\sim 1$ up to $\sim 11$ $\mathrm{mg} / \mathrm{g}$ as the $\mathrm{pH}$ of solution was increased from 3 to 9 . This behavior was attributed to the electrostatic attraction between EW and MB. The proteins found in EW comprise of many amino acids which have amino 


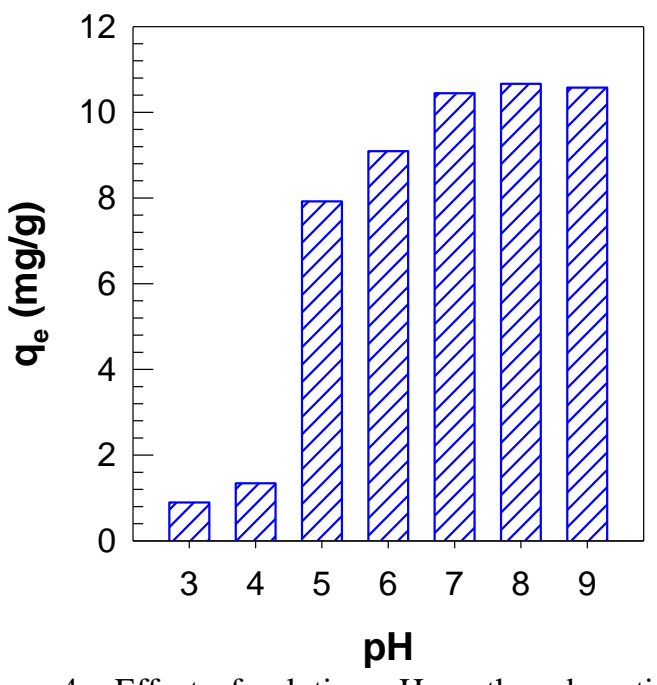

Figure 4. Effect of solution $\mathrm{pH}$ on the adsorption of $\mathrm{MB}\left(\mathrm{pH}=3-9, C_{o}=15 \mathrm{mg} / \mathrm{L}, t=24 \mathrm{~h}\right)$

and carbonyl functional groups. These active sites of the bioadsorbent can be strongly cationic or anionic depending on the $\mathrm{pH}$ of the medium. EW mainly consists of ovalbumin, ovotransferrin, lysozyme and ovomucin proteins. Ovalbumin (isoelectric point 4.5 ) content is about $54 \%$ of total protein of EW, so that it dominates the most of the functional groups in the biosorbent (Croguennec et al., 2000; Pereira et al., 2016). On the other hand, MB is heterocyclic aromatic chemical compound with a positive charge. Since the amino groups of EW are protonated at low $\mathrm{pH}$ of the solution, the repulsion occurred between the cryogel and cationic dye MB. The cryogel offered almost no adsorption towards to $\mathrm{MB}$ at $\mathrm{pH}=3$ and 4 , indicating that he electrostatic attraction was the main adsorption mechanism. When the $\mathrm{pH}$ of solution was above isoelectric point, the positive charged $\mathrm{MB}$ was

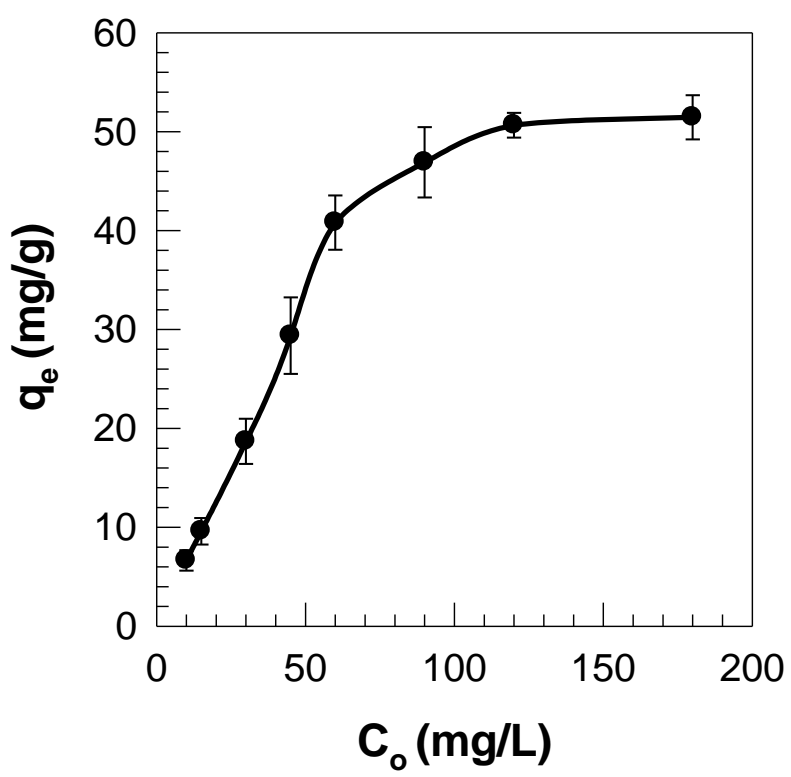

Figure 5. Effect of initial dye concentration on the adsorption of $\mathrm{MB}\left(C_{o}=10-180 \mathrm{mg} / \mathrm{L}, \mathrm{pH}=9, t=24 \mathrm{~h}\right)$ interacted with negative charged EW due to the dissociation of carbonyl groups and as a result, the adsorption capacity enhanced.

The adsorption performance of the cryogel was studied at dye concentration range from 10 to $180 \mathrm{mg} / \mathrm{L}$ at $\mathrm{pH} 9$ for $24 \mathrm{~h}$ contact time (Salazar-Rabago et al., 2017). The adsorption amount rose sharply until initial dye concentration increased to $100 \mathrm{mg} / \mathrm{L}$ and then reached a plateau value of $\sim 52 \pm 3 \mathrm{mg} / \mathrm{g}$ (Figure 5). It is explained by the fact that the adsorption capacity remained stable at high initial dye concentrations due to almost occupation of all active sites of the adsorbents, while the adsorption capacity was low due to the excess of adsorbent dose at low initial dye concentrations (Uddin et al., 2009).

\section{Adsorption Kinetics}

The MB adsorption on the cryogel as a function of contact time was also studied to evaluate the kinetics and gain insight into the underlying mechanisms. Figure 6 shows the adsorption performance depending on the time with a dye concentration of $15 \mathrm{mg} / \mathrm{L}$ at $\mathrm{pH}$ 9. Initially, the adsorption rate was high due to rich active sites for dye binding and decreased as time progressed. The adsorption almost reached to the equilibrium after $\sim 24 \mathrm{~h}$.

The adsorption rate, the model of process and interaction between $\mathrm{MB}$ and $\mathrm{EW}$ cryogel were analyzed by fitting the experimental data to pseudofirst order and pseudo-second order kinetic models using equation 7 and 8 , respectively. (Gerente et al., 2007).

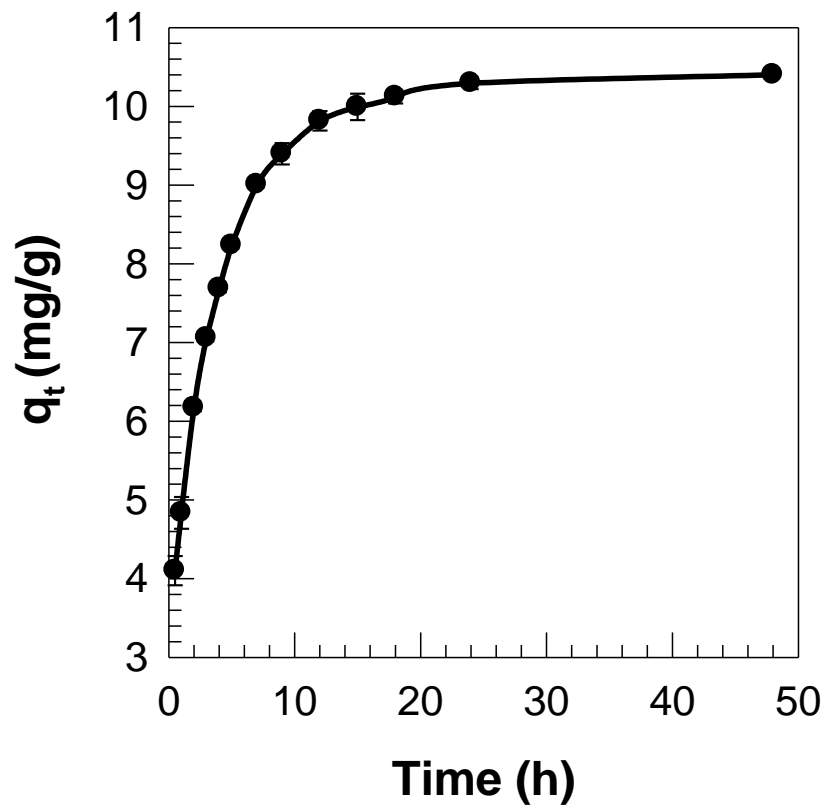

Figure 6. Effect of contact time on the adsorption of MB $(t$ $\left.=0.5-48 \mathrm{~h}, C_{o}=15 \mathrm{mg} / \mathrm{L}, \mathrm{pH}=9\right)$ 

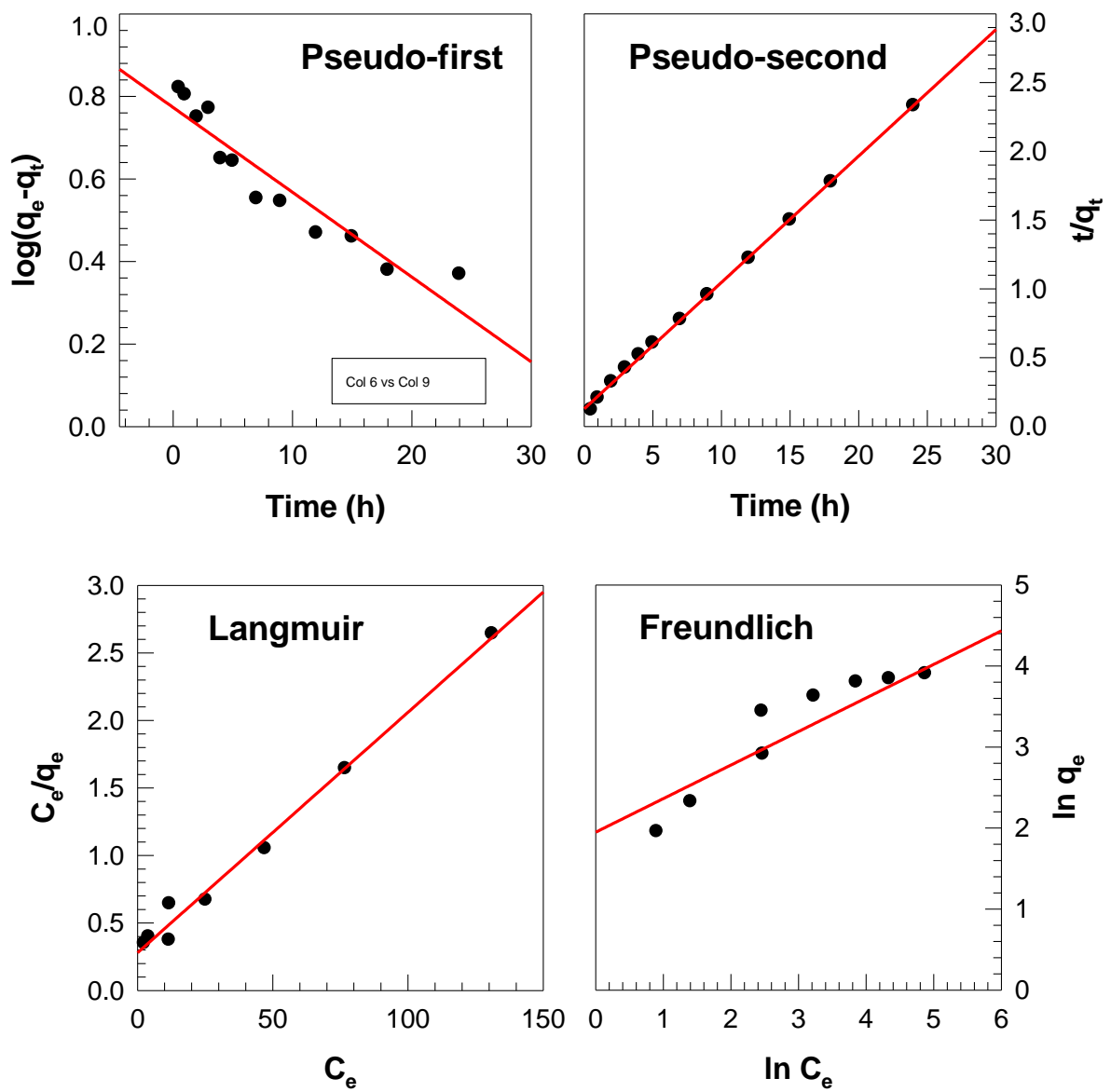

Figure 7. (Top) Kinetic and (bottom) isotherm models of the MB adsorption on the EW cryogel.

Pseudo-first order model (Lagergren, 1898):

$\log \left(q_{e}-q_{t}\right)=\log q_{e}-\frac{k_{1}}{2.303} t$

Pseudo-second order model (Ho, 2006):

$\frac{t}{q_{t}}=\frac{1}{k_{2} q_{e}^{2}}+\frac{t}{q_{e}}$

where $\mathrm{k}_{1}$ and $\mathrm{k}_{2}$ are the rate constants of models. Adsorption kinetic models provide insight about whether the adsorption process is physical or chemical. The slope lines of kinetic models for MB adsorption on the EW cryogel were drawn in Figure 7 and the corresponding kinetic parameters were collected in Table 2. The linear regression correlation coefficient $\left(\mathrm{R}^{2}=0.99\right)$ value from the pseudo-second order model was close to unity and higher than that $\left(\mathrm{R}^{2}=0.89\right)$ from the pseudo-first order model. Moreover, the experimental adsorption capacity $\left(q_{e, \exp }=10.40 \mathrm{mg} / \mathrm{g}\right)$ was similar to the calculated equilibrium adsorption capacity $\left(q_{e, c a l}=10.88 \mathrm{mg} / \mathrm{g}\right)$ of the pseudo-second order in contrast to the pseudo-first order $\left(q_{e, \text { cal }}=5.93\right.$ $\mathrm{mg} / \mathrm{g}$ ), indicating the adsorption process matched the pseudo-second order model and chemical adsorption dominated the process (Kuang et al., 2020). This behavior was consistent with many studies of MB adsorption on cryogel sorbents (Dragan \& Loghin, 2013).
Table 2. Calculated parameters from kinetic models for MB adsorption onto EW cryogel.

\begin{tabular}{cccc}
\multicolumn{4}{c}{ Pseudo-first order model } \\
\hline$C_{o}(\mathrm{mg} / \mathrm{L})$ & $q_{e}(\mathrm{mg} / \mathrm{g})$ & $k_{l}\left(\mathrm{~h}^{-1}\right)$ & $R^{2}$ \\
15 & 5.93 & 0.047 & 0.89 \\
\hline \hline \multicolumn{5}{c}{ Pseudo-second order model } \\
\hline$C_{o}(\mathrm{mg} / \mathrm{L})$ & $q_{e}(\mathrm{mg} / \mathrm{g})$ & $k_{2}(\mathrm{mg} / \mathrm{g} \mathrm{h})$ & $R^{2}$ \\
15 & 10.88 & 0.066 & 0.99
\end{tabular}

The intra-particle diffusion model was also applied on kinetic data by using Weber-Morris equation given below (Weber \& Morris, 1963). According to this model, the adsorption process is controlled by only intra-particle diffusion if the plot of $q_{t}$ against to $t^{0.5}$ gives a single straight line through the origin. Otherwise it is controlled by more than one step.

$q_{t}=k_{i d} t^{0.5}+C$

where $k_{i d}\left(\mathrm{mg} /\left(\mathrm{g} \cdot \mathrm{min}^{0.5}\right)\right)$ is rate constant and $C(\mathrm{mg} / \mathrm{g})$ is the constant related to boundary layer thickness. As can be seen in Figure 8, nonzero values (2.37 and 8.78) of constant $C$ and the multilinearity with two straight lines indicate that the adsorption mechanism consisted of multistep process (Doğan et al., 2009). This can be explained by that the diffusion of MB to the surface of EW cryogel and into the interior part through macropores is the first step, and reaching saturation with MB in active sites is the second step. 


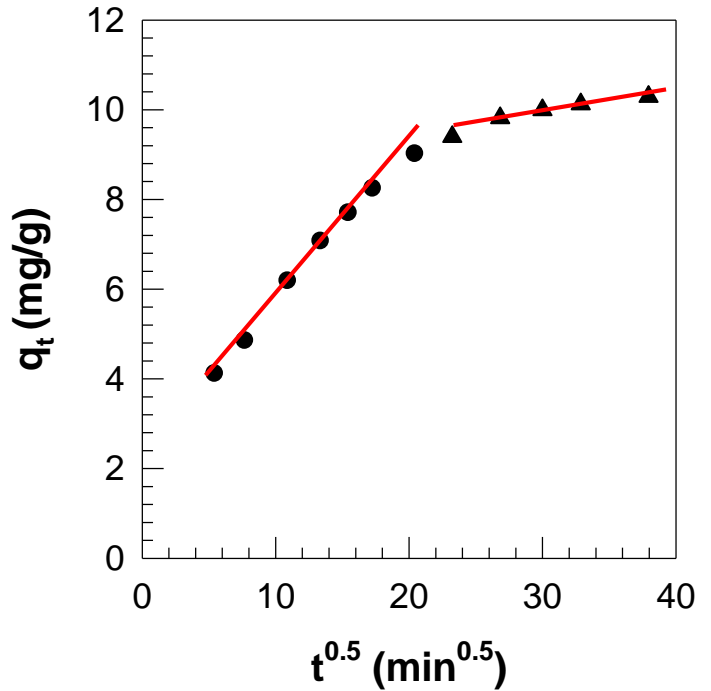

Figure 8. Intra-particle diffusion model of the MB adsorption on the EW cryogel.

\section{Adsorption Isotherms}

The experimental data obtained from the adsorption at various initial dye concentrations in the range from 10 to $180 \mathrm{mg} / \mathrm{L}$ (pH9, $\sim 10 \mathrm{mg}$ sorbent and $24 \mathrm{~h}$ contact time) were analyzed using most commonly known Langmuir and Freundlich isotherm models (Foo \& Hameed, 2010; Freundlich, 1907; Langmuir, 1918). The equations of these isotherm models are given below in equations 10 and 11 .

Langmuir isotherm: $\frac{C_{e}}{q_{e}}=\frac{1}{K_{L} q_{m}}+\frac{C_{e}}{q_{m}}$

(Eq.10)

Freundlich isotherm: $\ln q_{e}=\log K_{F}+\frac{1}{n} \ln C_{e}$

where $q_{m}(\mathrm{mg} / \mathrm{g})$ is the maximum adsorption capacity, $K_{L}(\mathrm{~L} / \mathrm{mg}), K_{F}(\mathrm{mg} / \mathrm{g}) /(\mathrm{mg} / \mathrm{L})^{1 / \mathrm{n}}$ and $n$ are constants.

Table 3. Calculated parameters from isotherm models for MB adsorption on the EW cryogel.

Langmuir isotherm model

\begin{tabular}{cccc}
\hline$C_{o}(\mathrm{mg} / \mathrm{L})$ & $q_{m}(\mathrm{mg} / \mathrm{g})$ & $K_{L}(\mathrm{~L} / \mathrm{mg})$ & $R^{2}$ \\
15 & 56.18 & 0.064 & 0.99 \\
\hline \hline \multicolumn{4}{c}{ Freundlich isotherm model } \\
\hline$C_{o}(\mathrm{mg} / \mathrm{L})$ & $n$ & $K_{F}(\mathrm{mg} / \mathrm{g}) /(\mathrm{mg} / \mathrm{L})^{1 / n}$ & $R^{2}$ \\
15 & 2.41 & 7.06 & 0.89
\end{tabular}

The linear regression lines of the models for $\mathrm{MB}$ adsorption onto the EW cryogel were drawn in Figure 7 and the corresponding parameters were collected in Table 3. The results indicated that the Langmuir model with correlation coefficient of $R^{2} \sim 0.99$ gave a better description of adsorption than the Freundlich model whose correlation coefficient value $\left(R^{2} \sim 0.89\right)$ was not close to unit. The maximum adsorption capacity $q_{m}$ of the cryogel found from Langmuir model was 56.18 $\mathrm{mg} / \mathrm{g}$, which was close to equilibrium adsorption capacity at plateau value of $\sim 52 \pm 3 \mathrm{mg} / \mathrm{g}$ in Figure 5. It can be assumed that the adsorption occurred on a homogeneous surface and in a monolayer rather than a reversible heterogeneous surface due to

$R_{\text {Langmuir }}^{2}>R_{\text {Freundlich }}^{2}$.

The separation factor $\left(R_{L}\right)$ is also used to depict the feasibility of the adsorption (Hall et al., 1966). It is calculated from $K_{L}$ using below equation,

$R_{L}=\frac{1}{1+K_{L} C_{o}}$

The type of the isotherm can be irreversible $\left(R_{L}=0\right)$, favorable $\left(0<R_{L}<1\right)$, linear $\left(R_{L}=1\right)$, or unfavorable $\left(R_{L}>1\right)$ according to the value of $R_{L}$. The calculated values of $R_{L}$ between 0.05 and 0.61 are plotted against the initial dye concentration in Figure 9, indicating the adsorption of $\mathrm{MB}$ on the $\mathrm{EW}$ cryogel was favorable for all studied dye concentrations.

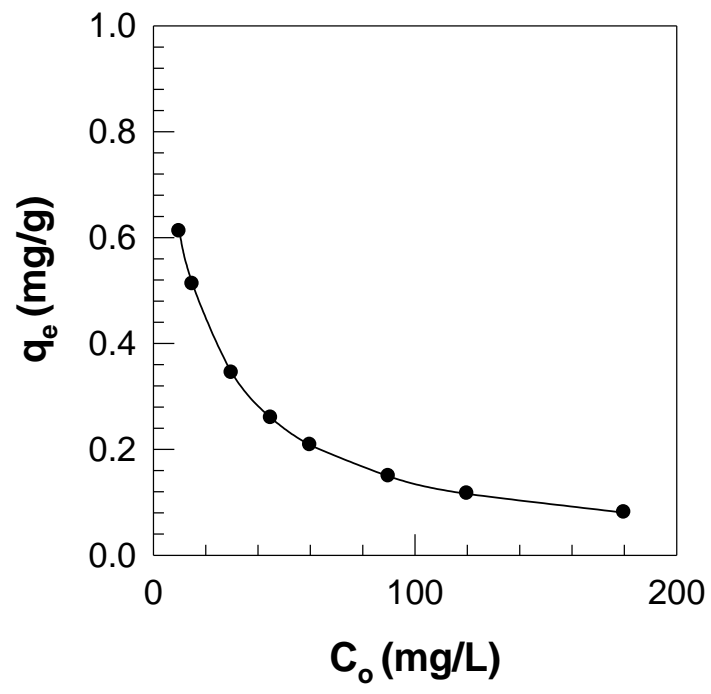

Figure 9. The separation factor $\left(R_{L}\right)$ values of $\mathrm{MB}$ adsorption on the EW cryogel.

\section{Desorption and reusability}

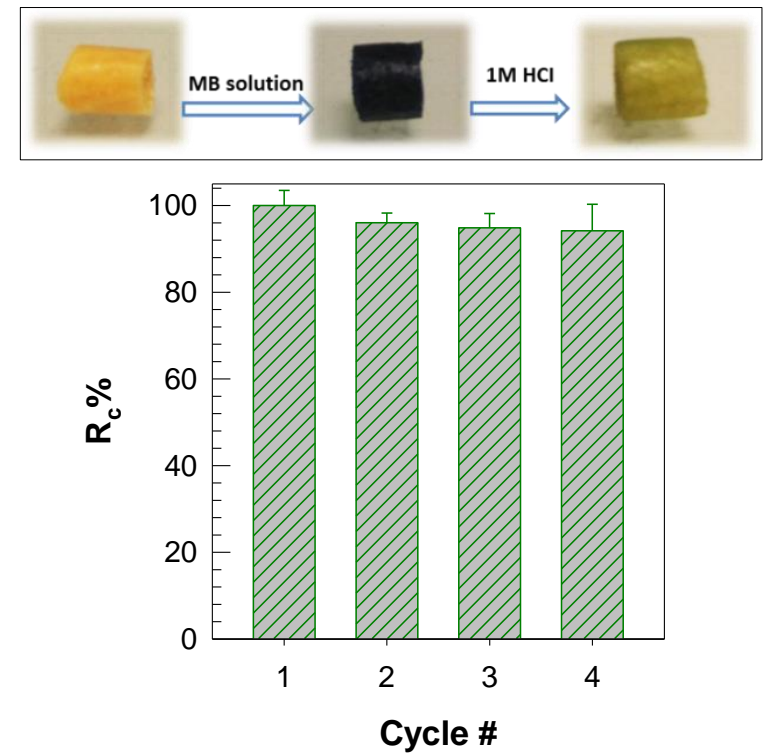

Figure 10. (Top) Digital photos of the EW cryogel before and after adsorption, and desorption of MB, respectively. (Bottom) the reusability of the EW cryogel $\left(\mathrm{C}_{\mathrm{o}}=15 \mathrm{mg} / \mathrm{L}, \mathrm{pH}=9\right.$ and $\left.\mathrm{t}=24 \mathrm{~h}\right)$. 
The reusability of the EW cryogel was conducted with four adsorption/desorption cycles. In the regeneration process, the dye adsorbed cryogel sample was firstly treated with $20 \mathrm{~mL}$ of $1 \mathrm{M} \mathrm{HCI}$ solution for $2 \mathrm{~h}$ (Figure 10). Then, the cryogel was separated and rinsed several times with water until neutral. The desorbed cryogel was used again for next adsorption cycle. The adsorption capacity of the cryogel remained almost the same and $R_{c} \%$ decreased only by $\sim 5$ without losing its mechanical stability after repeating cycles (Figure 10). These results show that almost complete desorption and reusability make the EW cryogel an economical and practical adsorbent in the wastewater treatment.

\section{Conclusion}

The study presented that the easily prepared EW cryogel can be efficiently used as sorbent for the removal MB from water. The adsorption amount of dye changed depending on the solution $\mathrm{pH}$, initial dye concentration and contact time. The equilibrium time was about $24 \mathrm{~h}$ and the removal efficiency was high at slightly basic $\mathrm{pH}$. The pseudo-second order kinetic model fitted $\left(R^{2}>0.99\right)$ with adsorption dynamics. Intraparticle diffusion model showed that there was more than one diffusion mode in the adsorption. According to the correlation coefficient $\left(R^{2}\right)$ values, the Langmuir isotherm model was more applicable with the adsorption data than that of the Freundlich one, confirming the monolayer sorption. The maximum MB adsorption capacity of the EW cryogel was $56.18 \mathrm{mg} / \mathrm{g}$. Furthermore, the prepared EW cryogel may be used as a potential bioadsorbent for removal of other contaminants from aqueous solution.

\section{Acknowledgements}

The author is grateful to Sevgi GULYUZ from TUBITAK MAM for FTIR and SEM measurements.

\section{References}

Balaji, P., Murugadas, A., Shanmugaapriya, S., Akbarsha, M. A. (2019). Fabrication and characterization of egg white cryogel scaffold for three-dimensional (3D) cell culture. Biocatalysis and Agricultural Biotechnology, 17, 441-446.

Bayramoglu, G., Altintas, B., Arica, M. Y. (2009). Adsorption kinetics and thermodynamic parameters of cationic dyes from aqueous solutions by using a new strong cation-exchange resin. Chemical Engineering Journal, 152(2-3), 339-346.

Bolto, B., Gregory, J. (2007). Organic polyelectrolytes in water treatment. Water research, 41(11), 23012324.

Crini, G. (2006). Non-conventional low-cost adsorbents for dye removal: a review. Bioresource technology, 97(9), 1061-1085.

Crini, G., Badot, P.-M. (2008). Application of chitosan, a natural aminopolysaccharide, for dye removal from aqueous solutions by adsorption processes using batch studies: A review of recent literature. Progress in Polymer Science, 33(4), 399-447.

Croguennec, T., Nau, F., Pezennec, S., Brule, G. (2000). Simple rapid procedure for preparation of large quantities of ovalbumin. Journal of Agricultural and Food Chemistry, 48(10), 48834889.

Dalaran, M., Emik, S., Güçlü, G., İyim, T. B., Özgümüş, S. (2011). Study on a novel polyampholyte nanocomposite superabsorbent hydrogels: Synthesis, characterization and investigation of removal of indigo carmine from aqueous solution. Desalination, 279(1), 170-182.

Dinu, M. V., Ozmen, M. M., Dragan, E. S., Okay, O. (2007). Freezing as a path to build macroporous structures: superfast responsive polyacrylamide hydrogels. Polymer, 48(1), 195-204.

Dinu, M. V., Perju, M. M., Drăgan, E. S. (2011). Porous Semi-Interpenetrating Hydrogel Networks Based on Dextran and Polyacrylamide With Superfast Responsiveness. Macromolecular Chemistry and Physics, 212(3), 240-251.

Doğan, M., Abak, H., Alkan, M. (2009). Adsorption of methylene blue onto hazelnut shell: kinetics, mechanism and activation parameters. Journal of Hazardous Materials, 164(1), 172-181.

Dragan, E. S., Loghin, D. F. A. (2013). Enhanced sorption of methylene blue from aqueous solutions by semi-IPN composite cryogels with anionically modified potato starch entrapped in PAAm matrix. Chemical Engineering Journal, 234, 211-222.

Erdem, A., Ngwabebhoh, F. A., Yildiz, U. (2017). Novel macroporous cryogels with enhanced adsorption capability for the removal of $\mathrm{Cu}(\mathrm{II})$ ions from aqueous phase: Modelling, kinetics and recovery studies. Journal of Environmental Chemical Engineering, 5(1), 1269-1280.

Foo, K. Y., Hameed, B. H. (2010). Insights into the modeling of adsorption isotherm systems. Chemical Engineering Journal, 156(1), 2-10.

Freundlich, H. (1907). Über die adsorption in lösungen. Zeitschrift für physikalische Chemie, 57(1), 385-470.

Garidel, P., Schott, H. (2006). Fourier-Transform Midinfrared Spectroscopy for Analysis and Screening of Liquid Protein Formulations Part 2 : Detailed Analysis and Applications.

Gerente, C., Lee, V., Cloirec, P. L., McKay, G. (2007). Application of chitosan for the removal of metals from wastewaters by adsorption-mechanisms and models review. Critical reviews in environmental science and technology, 37(1), 41-127.

Godiya, C. B., Sayed, S. M., Xiao, Y., Lu, X. (2020). Highly porous egg white/polyethyleneimine hydrogel for rapid removal of heavy metal ions and catalysis in wastewater. Reactive and Functional Polymers, 149, 104509.

Hall, K. R., Eagleton, L. C., Acrivos, A., Vermeulen, T. (1966). Pore-and solid-diffusion kinetics in fixed-bed adsorption under constant-pattern conditions. Industrial \& Engineering Chemistry Fundamentals, 5(2), 212-223. 
Hasanpour, M., Hatami, M. (2020). Photocatalytic performance of aerogels for organic dyes removal from wastewaters: Review study. Journal of Molecular Liquids, 113094.

He, X., Male, K. B., Nesterenko, P. N., Brabazon, D., Paull, B., Luong, J. H. (2013). Adsorption and desorption of methylene blue on porous carbon monoliths and nanocrystalline cellulose. ACS Applied Materials \& Interfaces, 5(17), 8796-8804.

Henderson, T. M. A., Ladewig, K., Haylock, D. N., McLean, K. M., O'Connor, A. J. (2013). Cryogels for biomedical applications, Journal of Materials Chemistry B, 1(21), 2682-2695.

Ho, Y.-S. (2006). Review of second-order models for adsorption systems. Journal of Hazardous Materials, 136(3), 681-689.

Hu, T., Liu, Q., Gao, T., Dong, K., Wei, G., Yao, J. (2018). Facile preparation of tannic acid-poly (vinyl alcohol)/sodium alginate hydrogel beads for methylene blue removal from simulated solution. ACS omega, 3(7), 7523-7531.

Huang, X.-Y., Mao, X.-Y., Bu, H.-T., Yu, X.-Y., Jiang, G.-B., Zeng, M.-H. (2011). Chemical modification of chitosan by tetraethylenepentamine and adsorption study for anionic dye removal. Carbohydrate Research, 346(10), 1232-1240.

Kanaujiya, D. K., Paul, T., Sinharoy, A., Pakshirajan, K. (2019). Biological Treatment Processes for the Removal of Organic Micropollutants from Wastewater: a Review. Current Pollution Reports, 5(3), 112-128.

Karabayir, E., Ozdemir, A., Senkal, B. F., Taskin, O. S. (2019). A radioactively durable melamine-styrene based polymer: highly efficient removal of $90 \mathrm{Sr}$. Applied Radiation and Isotopes, 149, 96-103.

Kuang, Y., Zhang, X., Zhou, S. (2020). Adsorption of Methylene Blue in Water onto Activated Carbon by Surfactant Modification. Water, 12(2), 587.

Kumar, K. V., Sivanesan, S. (2006). Equilibrium data, isotherm parameters and process design for partial and complete isotherm of methylene blue onto activated carbon. Journal of Hazardous Materials, 134(1-3), 237-244.

Lagergren, S. K. (1898). About the theory of so-called adsorption of soluble substances. Sven. Vetenskapsakad. Handingarl, 24, 1-39.

Langmuir, I. (1918). The adsorption of gases on plane surfaces of glass, mica and platinum. Journal of the American Chemical society, 40(9), 1361-1403.

Lozinsky, V. I., Plieva, F. M., Galaev, I. Y., Mattiasson, B. (2001). The potential of polymeric cryogels in bioseparation. Bioseparation, 10(4), 163-188.

Oymak, T., Bağda, E. (2018). Crosslinked egg white as eco-friendly, reusable, and cost-effective biosorbent for rapid removal of indigo carmine. CLEAN-Soil, Air, Water, 46(6), 1700186.

Pereira, M. M., Cruz, R. A., Almeida, M. R., Lima, Á. S., Coutinho, J. A., Freire, M. G. (2016). Singlestep purification of ovalbumin from egg white using aqueous biphasic systems. Process Biochemistry, 51(6), 781-791.
Rocher, V., Bee, A., Siaugue, J.-M., Cabuil, V. (2010). Dye removal from aqueous solution by magnetic alginate beads crosslinked with epichlorohydrin. Journal of Hazardous Materials, 178(1), 434-439.

Salazar-Rabago, J. J., Leyva-Ramos, R., Rivera-Utrilla, J., Ocampo-Perez, R., Cerino-Cordova, F. J. (2017). Biosorption mechanism of Methylene Blue from aqueous solution onto White Pine (Pinus durangensis) sawdust: effect of operating conditions. Sustainable Environment Research, 27(1), 32-40.

Uddin, M. T., Islam, M. A., Mahmud, S., Rukanuzzaman, M. (2009). Adsorptive removal of methylene blue by tea waste. Journal of Hazardous Materials, 164(1), 53-60.

Weber, W. J., Morris, J. C. (1963). Kinetics of adsorption on carbon from solution. Journal of the sanitary engineering division, 89(2), 31-60. 